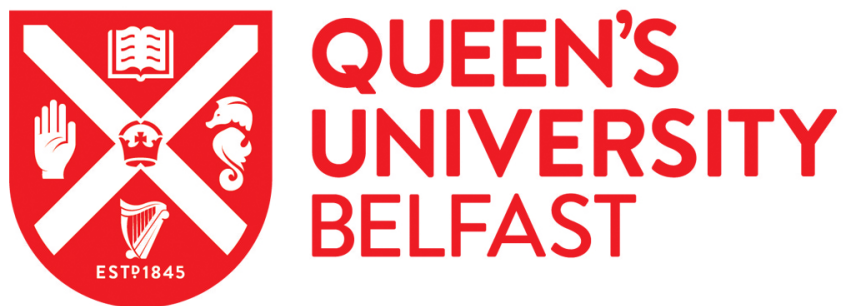

\section{Priorities for research in soil ecology}

Eisenhauer, N., Autunes, P. M., Bennett, A. E., Birkhofer, K., Bissett, A., Bowker, M. A., Caruso, T., Chen, B., David C. Coleman, Wietse de Boer, Peter de Ruiter, Thomas H. DeLuca, Francesco Frati, Bryan S. Griffiths, Miranda M. Hart, Stephan Hättenschwiler, Jari Haimit, Michael Heethoff, Nobuhiro Kaneko, ... Powell, J. R. (2017). Priorities for research in soil ecology. Pedobiologia, 63, 1-7. https://doi.org/10.1016/j.pedobi.2017.05.003

\section{Published in: \\ Pedobiologia}

\section{Document Version:}

Peer reviewed version

\section{Queen's University Belfast - Research Portal:}

Link to publication record in Queen's University Belfast Research Portal

\section{Publisher rights}

(C) 2017 Elsevier $\mathrm{GmbH}$

This manuscript is distributed under a Creative Commons Attribution-NonCommercial-NoDerivs License

(https://creativecommons.org/licenses/by-nc-nd/4.0/), which permits distribution and reproduction for non-commercial purposes, provided the author and source are cited

\section{General rights}

Copyright for the publications made accessible via the Queen's University Belfast Research Portal is retained by the author(s) and / or other copyright owners and it is a condition of accessing these publications that users recognise and abide by the legal requirements associated with these rights.

\section{Take down policy}

The Research Portal is Queen's institutional repository that provides access to Queen's research output. Every effort has been made to ensure that content in the Research Portal does not infringe any person's rights, or applicable UK laws. If you discover content in the Research Portal that you believe breaches copyright or violates any law, please contact openaccess@qub.ac.uk. 
Opinion Paper

\section{Priorities for research in soil ecology}

Nico Eisenhauer ${ }^{1,2, \#, *, \text { Pedro M. Antunes }}{ }^{3}$, Alison E. Bennett ${ }^{4}$, Klaus Birkhofer $^{5}$, Andrew $^{-}$ Bissett $^{6}$, Matthew A. Bowker 7 , Tancredi Caruso ${ }^{8}$, Baodong Chen $^{9,10}$, David C. Coleman ${ }^{11}$, Wietse de Boer ${ }^{12,13}$, Peter de Ruiter ${ }^{14}$, Thomas H. DeLuca ${ }^{15}$, Francesco Frati' ${ }^{16}$, Bryan S. Griffiths $^{17}$, Miranda M. Hart ${ }^{18}$, Stephan Hättenschwiler ${ }^{19}$, Jari Haimi ${ }^{20}$, Michael Heethoff $^{21}$, Nobuhiro Kaneko ${ }^{22}$, Laura C. Kelly ${ }^{23}$, Hans Petter Leinaas ${ }^{24}$, Zö̈ Lindo ${ }^{25}$, Catriona Macdonald ${ }^{26}$, Matthias C. Rillig ${ }^{27,28}$, Liliane Ruess ${ }^{29}$,Stefan Scheu ${ }^{30}$, Olaf Schmidt $^{31}$, Timothy R. Seastedt ${ }^{32}$, Nico M. van Straalen ${ }^{33}$, Alexei V. Tiunov ${ }^{34}$, Martin Zimmer $^{35}$, Jeff R. Powell ${ }^{26, \#}$

${ }^{1}$ German Centre for Integrative Biodiversity Research (iDiv) Halle-Jena-Leipzig, Deutscher Platz 5e, 04103 Leipzig, Germany

${ }^{2}$ Institute of Biology, Leipzig University, Johannisallee 21, 04103 Leipzig, Germany

${ }^{3}$ Department of Biology, Algoma University, 1520 Queen Street East, Sault Ste. Marie, ON, P6A 2 G4 Canada

${ }^{4}$ Ecological Sciences, James Hutton Institute, Errol Road, Invergowrie, Dundee DD2 5DA United Kingdom

${ }^{5}$ Chair of Ecology, Brandenburg University of Technology Cottbus-Senftenberg, Konrad-WachsmannAllee 6, 03046 Cottbus, Germany

${ }^{6}$ CSIRO Oceans and Atmosphere, Hobart, TAS 7000, Australia 
${ }^{7}$ School of Forestry, Northern Arizona University, 200 East Pine Knoll Drive, Flagstaff, Arizona 86011, USA

${ }^{8}$ School of Biological Sciences and Institute for Global Food Security, Queen's University of Belfast, 97 Lisburn Road, Belfast, BT9 7BL, Northern Ireland

${ }^{9}$ State Key Laboratory of Urban and Regional Ecology, Research Center for Eco-Environmental Sciences, Chinese Academy of Sciences, 18 Shuangqinglu, Haidian District, Beijing 100085, China

${ }^{10}$ University of Chinese Academy of Sciences, 19 Yuquanlu, Shijingshan District, Beijing 100049, China

${ }^{11}$ Odum School of Ecology, University of Georgia, Athens, Georgia 30602, USA

${ }^{12}$ Department of Microbial Ecology, Netherlands Institute of Ecology (NIOO-KNAW), Wageningen, 6708 PB, The Netherlands;

${ }^{13}$ Department of Soil Quality, Wageningen University, Wageningen, 6708 PB, the Netherlands

${ }^{14}$ Institute for Biodiversity and Ecosystem Dynamics (IBED), Faculty of Science, Universiteit van Amsterdam, Science Park 904, 1098 XH Amsterdam, The Netherlands

${ }^{15}$ School of Environmental and Forest Sciences, University of Washington, Box 352100, Seattle, WA 98195-2100, USA

${ }^{16}$ Department of Life Sciences, University of Siena, via Aldo Moro 2, 53100, Siena, Italy

${ }^{17}$ Crop and Soil Systems Research Group, Scotland's Rural College, West Mains Road, Edinburgh, EH9 3JG, United Kingdom

${ }^{18}$ Department of Biology, University of British Columbia, Okanagan Campus, 3187 University Way, Kelowna, BC, Canada

${ }^{19}$ Centre d'Ecologie Fonctionnelle et Evolutive (CEFE) UMR 5175, CNRS - Université de Montpellier

- Université Paul-Valéry Montpellier - EPHE, 1919 Route de Mende, 34293 Montpellier, France

${ }^{20}$ Department of Biological and Environmental Science, University of Jyväskylä, P.O.Box 35, FI- 
40014, Finland

${ }^{21}$ Ecological Networks, TU Darmstadt, Schnittspahnstr. 3, 64287 Darmstadt

${ }^{22}$ Soil Ecology Research Group, Yokohama National University ,79-7 Tokiwadai, Hodogaya, Yokohama 240-8501, Japan

${ }^{23}$ Division of Biology and Conservation Ecology, Manchester Metropolitan University, Oxford Road, M1 5GD, United Kingdom

${ }^{24}$ Department of Biosciences, University of Oslo, PO Box 1066 Blindern, 0316 Oslo, Norway

${ }^{25}$ Department of Biology, The University of Western Ontario, London, Ontario, Canada N6A 5B7

${ }^{26}$ Hawkesbury Institute for the Environment, Western Sydney University, Locked Bag 1797, Penrith NSW 2751, Australia

${ }^{27}$ Institute of Biology, Freie Universität Berlin, Altensteinstr. 6, 14195 Berlin, Germany

${ }^{28}$ Berlin-Brandenburg Institute of Advanced Biodiversity Research (BBIB), 14195 Berlin, Germany

${ }^{29}$ Institute of Biology, Ecology Group, Humboldt-Universität zu Berlin, Philippstr. 13, 10115 Berlin, Germany

${ }^{30}$ JFB Institute of Zoology and Anthropology, University of Göttingen, Berliner Str. 28, 37073

Göttingen, Germany

${ }^{31}$ UCD School of Agriculture and Food Science, University College Dublin, Belfield, Dublin 4, Ireland

${ }^{32}$ Department of Ecology and Evolutionary Biology, Institute of Arctic and Alpine Research, University of Colorado, Boulder, UCB 450, CO 80309, USA

${ }^{33}$ Department of Ecological Science, Vrije Universiteit Amsterdam, De Boelelaan 1085, $1081 \mathrm{HV}$ Amsterdam, The Netherlands

${ }^{34}$ A.N. Severtsov Institute of Ecology and Evolution RAS, Leninsky Prospect 33, 119071 Moscow, Russia 
Eisenhauer et al. | Priorities for research in soil ecology

${ }^{35}$ Leibniz-Centre for Tropical Marine Research, Fahrenheitstr. 6, 28359 Bremen

${ }^{\text {\# } A u t h o r s ~ c o n t r i b u t e d ~ e q u a l l y ; ~ a l l ~ o t h e r ~ a u t h o r s ~ a r e ~ l i s t e d ~ a l p h a b e t i c a l l y ~}$

*Corresponding author: nico.eisenhauer@idiv.de 


\section{Abstract}

The ecological interactions that occur in and with soil are of consequence in many ecosystems on the planet. These interactions provide numerous essential ecosystem services, and the sustainable management of soils has attracted increasing scientific and public attention. Although soil ecology emerged as an independent field of research many decades ago, and we have gained important insights into the functioning of soils, there still are fundamental aspects that need to be better understood to ensure that the ecosystem services that soils provide are not lost and that soils can be used in a sustainable way. In this perspectives paper, we highlight some of the major knowledge gaps that should be prioritized in soil ecological research. These research priorities were compiled based on an online survey of 32 editors of Pedobiologia - Journal of Soil Ecology. These editors work at universities and research centers in Europe, North America, Asia, and Australia. The questions were categorized into four themes: (1) soil biodiversity and biogeography, (2) interactions and the functioning of ecosystems, (3) global change and soil management, and (4) new directions. The respondents identified priorities that may be achievable in the near future, as well as several that are currently achievable but remain open. While some of the identified barriers to progress were technological in nature, many respondents cited a need for substantial leadership and goodwill among members of the soil ecology research community, including the need for multi-institutional partnerships, and had substantial concerns regarding the loss of taxonomic expertise. 


\section{Keywords}

Aboveground-belowground interactions; biodiversity-ecosystem functioning; biogeography; chemical ecology; climate change; ecosystem services; global change; microbial ecology; novel environments; plant-microbe interactions; soil biodiversity; soil food web; soil management; soil processes

\section{Introduction}

Many, if not most, of the ecosystems on Earth are dependent on, or substantially influenced by, interactions and processes occurring within and among the planet's soils (including sediments). The remarkable biodiversity harbored in soil provides essential ecosystem services (Bardgett and van der Putten, 2014; Wall et al., 2015), and the sustainable management of soils has attracted ever-increasing scientific attention (Wall et al., 2015). Soil organisms and how they drive the processes that underlie essential ecosystem services have fascinated and challenged soil ecologists for decades (Powell et al., 2014). Their importance and complexity are increasingly arousing public and political interest in soil, such as that exemplified by the International Year of Soils in 2015 (Powell and Eisenhauer, 2015) and the annual celebration of World Soil Day (every December $5^{\text {th }}$, since 2002). Many policy makers 
and land managers are realizing that soil ecological knowledge is key for sustainable environmental management, for the protection and conservation of soils, and for the nutrition and health of an increasing human population (Wall et al., 2015; Keith et al., 2016). However, despite these points, many knowledge gaps still exist and hinder researchers from making specific recommendations about soil conservation issues (Phillips et al., 2017) to maintain soil processes linked to ecosystem services under increasing human pressure and global change. As a consequence, soil ecology will remain an extremely important field of research into the future and requires a coordinated global effort to address the most important issues facing the sustainability of soils and gaps in soil ecological knowledge.

In this perspectives paper, we highlight what we have identified as the most crucial and emerging questions in soil ecological research. These research priorities were compiled based on an online survey of 32 editors of Pedobiologia - Journal of Soil Ecology. Thus, this list of questions may not be exhaustive and certainly contains some geographical biases (Fig. 1), but we are confident that they will serve as a constructive collection of ideas to target future research and facilitate progress in soil ecology.

\section{Survey}


Thirty-two editors of Pedobiologia - Journal of Soil Ecology participated in the online survey in September and October of 2015. These editors work at universities and research centers in Europe, North America, Asia, and Australia (Fig. 1) and cover many different disciplines in soil ecology (Fig. 2). All of them provided responses to the following five questions/requests:

1. Please list 5-10 outstanding research questions in soil ecology that, in your opinion, should be prioritized.

2. Which of these priorities are currently achievable given available technological or analytical resources?

3. For the achievable priorities, please state, in your opinion, why these have not been achieved.

4. For the priorities that are not currently achievable, what technological or analytical advances are required to facilitate research into these priorities?

5. Which research themes/keywords best represent the majority of your research?

Overall, we received 214 responses to question \#1. Questions were screened, similar questions were merged, and then questions were grouped in the following four categories: (1) soil biodiversity and biogeography, (2) interactions and the functioning of ecosystems, (3) global change and soil management, and (4) new directions. In total, 117 questions were identified, and we then asked all editors to vote for the most pressing questions to be addressed in each category. The questions that were supported by at least six of the 23 respondents (>25\%) to this second survey are presented below. Within each section, the 
questions are proposed in order of decreasing support; all proposed questions and their level of support are provided in the supplementary online material. Responses to questions/requests 2-5 of the initial survey are summarized in the sections "New directions" and "Conclusions".

\section{Soil biodiversity and biogeography}

Currently, there is a focused and highly dynamic research effort to understand how biodiversity, in general, is changing and what is driving this change (Vellend et al., 2013; Dornelas et al., 2014; Wright et al., 2014; McGill, 2015; Gonzalez et al., 2016; Vellend et al., 2017). Remarkably, information on soil biodiversity is lagging behind compared to the diversity of other groups of organisms, and the underlying databases and analyses are largely lacking comprehensive information pertaining to soil biodiversity (Phillips et al., 2017). This gap is probably due to limited and patchy data on soil biodiversity, particularly the absence of surveys with explicit temporal and spatial perspectives (Phillips et al., 2017), and difficulties comparing studies using different methodologies. Soil ecologists are still trying to determine the main drivers of soil biodiversity patterns (Fierer and Jackson, 2006; Powell et al., 2015a) and the fate of soil biodiversity in the face of global environmental change (Maestre et al., 2015; Veresoglou et al., 2015).

According to the Global Soil Biodiversity Atlas (2016), remarkably few species of soil taxa 
have currently been described, with estimates ranging from $<1 \%$ for protists, $<1.5 \%$ for bacteria, $<7 \%$ for fungi, $17 \%$ for Collembola, $23 \%$ for earthworms, to $55 \%$ in mites. These values are much less than what has been described for other taxa (e.g., $\sim 88 \%$ of vascular plants have already been described). In addition, even when taxonomic information is available, much less is known about the functional roles of the great majority of these organisms within the ecosystems in which they occur (e.g., Janion-Scheepers et al., 2016). On top of this, bridging the vast gap in the spatial and temporal scales at which soil ecology is usually studied (e.g. small-scale biodiversity descriptions, short-term experiments in the laboratory) and scales at which ecosystems are managed in the real world (e.g. spanning from months to decades and from hectares to continents) remains a challenge (Jiang et al., 2016). Moreover, there has been little exploration of the roles that evolution has played in shaping soil biodiversity, and this has largely been biased towards a small subset of mutualistic or parasitic soil biota (Blaxter et al., 1998; Masson-Boivin et al., 2009; Tedersoo et al., 2010). As such, we are greatly limited in our abilities to address even the most basic questions, such as how much of the world's biodiversity is found in soils, and answers to questions relating to the main driving factors behind microbial biogeography are highly context-dependent. Further, while we are starting to address the questions of whether communities of certain organisms assemble in fundamentally different ways in soils due to the massive interchange that occurs among these communities (Rillig et al., 2016), there may be additional consequences for the evolution of soil biota that are not being addressed (Antwis et al., 2017).

The following section summarizes research questions that relate to the drivers of soil 
biodiversity, the study of underlying evolutionary processes, and linkages to ecosystem responses at larger spatial scales.

\section{Drivers of soil biodiversity}

1. How important are root and litter traits in determining the diversity and abundance of soil organisms?

2. Are there ecological assembly rules that determine community composition and structure, and what are the important mechanisms underlying these rules (dispersal limitation, species sorting, competition, facilitation, etc.)?

3. To what extent does niche differentiation occur for soil organisms, and what are the important mechanisms that contribute to this differentiation?

4. How do climatic conditions, parent material, vegetation type, and the distribution of mineral and organic surfaces in soil interact in shaping communities of soil biota?

5. What are the drivers of the phenology of soil organisms and processes, and how do we develop robust sampling strategies to effectively take these into account?

6. What consequences do dispersal limitations of soil organisms have for the 
genetic structure and adaptability of populations of soil organisms?

7. How prevalent is endemism in soil biota?

\section{Evolution}

8. How frequent is horizontal exchange of genetic material among viruses, animals, plants, and microbes in soil, and does this differ from what is observed in aquatic systems?

9. What is the reason for the high frequency of parthenogenesis in some soil animal species and its absence in certain lineages, and what is its consequence for the evolution of these species?

10. How important is epigenetic regulation of gene expression for evolutionary and ecological processes in soil?

\section{Scaling up}

11. What is the degree of functional redundancy of soil communities, and does it 
vary among ecosystem types?

12. Can biogeochemical process models be improved by including information regarding the soil organisms present?

13. Are there emergent properties at the landscape scale that arise from processes measured at much smaller scales, and can these properties be predicted from known soil ecological principles?

14. Are there general patterns that can be inferred from spatial associations between resources and consumers in soil?

15. Are genomic measures of functionality in soil useful predictors of ecosystem process rates and stability?

16. How large is the flux of greenhouse gases from soil environments, and what are the ecological controls of these quantities?

\section{Interactions among soil organisms and the functioning of}

\section{ecosystems}

Despite their functional significance, trophic and non-trophic interactions among soil organisms are still poorly understood (Bardgett and van der Putten, 2014). There is increasing awareness of the need to explore species interactions in complex food webs to understand the 
provisioning of multiple ecosystem services (Thompson et al., 2012, Hines et al., 2015; Soliveres et al., 2016). In this context, a perspective that encompasses the whole soil ecosystem, from soil aggregates and the interactions within (Maaß et al., 2015) to the interactions between aboveground-belowground food webs (Eisenhauer et al., 2015; Hines et al., 2015) and involving ecosystem engineers (Jones et al., 1994), is needed to connect different compartments.

For trophic relationships, major advances can be made by better connecting the microbial utilization of plant-derived substrates to the movement of elements through faunal energy and nutrient pathways in soil, which are then linked to aboveground communities by plants and epigeic generalist predators (Scheu, 2001; Wardle et al., 2004; Scherber et al., 2010). Nontrophic relationships also play important roles, such as during the chemical mediation of species interactions in soil (van Dam and Bouwmeester, 2016), and behaviors arising during quorum sensing and swarming by soil microorganisms with subsequent effects of soil biota on plant growth (Phillips et al., 2003). Both trophic and non-trophic relationships can serve to link above- and belowground compartments, such as plant defenses against herbivores and pathogens being influenced, partly, by changes in belowground plant chemistry (Johnson et al., 2016) or vice versa. Central to these phenomena is the observation that complex networks of interactions can have emergent properties that influence network and ecosystem stability (Rooney et al., 2006; Neutel et al., 2007; Hines et al. 2015). We know about trophic networks in soil (Moore et al., 2005), but mostly at low taxonomic resolution and relatively little with regards to networks of mutualists in soil and the specificity of mutualistic interactions. Also, 
those networks are not well placed to determine whether the structure of mutualistic networks belowground can be inferred from knowledge generated during the study of aboveground mutualisms.

The following section summarizes questions related to interactions within soil food webs, whether direct (through trophic interactions) or indirect (through chemical interactions or via effects on soil physical characteristics); how these interactions are linked to aboveground communities; and what the consequences are of soil biodiversity and interactions among soil organisms for ecosystem processes.

\section{Soil food webs and interactions therein}

17. How important is facilitation among soil organisms, and what are the underlying mechanisms (e.g., chemical/physical) of facilitative interactions?

18. What is the relative contribution of top-down versus bottom-up control within soil food webs, and does their importance vary among food web compartments?

19. How important are mutualists, parasites, and viral diseases in regulating the functioning and assembly of soil communities?

20. What is the role of info-chemicals for microbe-plant, microbe-animal, and animal-plant interactions in soil, and how are chemical signals transmitted 
effectively in a humus-rich environment?

21. How important are interactions among soil microorganisms for energy flows in food webs relative to interactions among soil fauna?

22. Do saprotrophic microorganisms and soil animals compete for resources, and do these interactions affect energy flows and nutrient stoichiometry?

23. How temporally stable are soil microbial communities, in terms of both taxonomic and functional community structure, and which community members are active at any one time?

24. Does functional redundancy in the traits expressed by multiple species lead to predictable outcomes from species interactions in soil despite differences in species composition?

\section{Linking ecosystem compartments}

25. How can we link belowground to aboveground food webs in dynamic models?

26. How does biodiversity in soil affect the diversity of other, connected environments in aquatic systems, and how important are temporarily flooded soils/sediments in linking diversity in these environments? 
27. Are microbial communities in plant and animal tissues aboveground, in the litter layer, and in the soil functionally linked?

28. Do effects of landscape composition (diversity and composition of different adjacent ecosystems) and fragmentation on aboveground taxa lead to cascading effects on soil biota?

29. Is the weak link between biodiversity above- and belowground due to soil organisms being limited more by resources arising from belowground sources (e.g., minerals arising from weathering) compared with aboveground sources (e.g., carbon from photosynthesis)?

30. What is the relative contribution of above- and belowground plant residues for the nutrition of soil food webs?

\section{Soil biodiversity-ecosystem functioning}

31. Can ecosystem functions be predicted from the trait composition of soil communities?

32. Does intraspecific genetic diversity contribute to variation in ecosystem functioning?

33. What are the tipping points, with respect to species losses or disturbances to 
ecosystems, that result in loss of soil functions?

34. How do soil biodiversity and ecological interactions in soil contribute to multiple ecosystem services, such as carbon sequestration, disease suppression, and maintenance of aboveground biodiversity?

35. How active are rare species in soil ecosystems, and do they provide significant contributions toward ecosystem functions?

36. What is the relative importance of biotic and abiotic drivers for decomposition and the subsequent cycling of elements in different soil types and ecosystems?

\section{Global change and soil management}

Anthropogenic environmental change is altering the composition and biodiversity of ecosystems at an unprecedented rate (Millennium Ecosystem Assessment, 2005; Ceballos et al., 2015) with poorly understood consequences for the functioning of ecosystems. While biodiversity-ecosystem functioning research has provided compelling evidence regarding the significance of biodiversity for the functioning of ecosystems (e.g., Hooper et al., 2005; Cardinale et al., 2012), the role of soil biodiversity (Bardgett and van der Putten, 2014) and the ways in which soil communities will change in response to altered environments (Veresoglou et al., 2015) are less clear (but see e.g., Blankinship et al., 2011 and Powell et al., 
2015b). Environmental change may have substantial direct impacts on soil organisms and ecological processes that have consequences for soil fertility (Maestre et al., 2015), which may then result in feedbacks by which fertility shifts go on to impact those communities of soil organisms (Leff et al., 2015). How soils are physically and chemically managed has also been the focus of several studies, and while these types of environmental change are likely strong determinants of soil biodiversity and compositional shifts, the context-dependence (Deng et al., 2015; Hewins et al., 2015) and temporal nature (Venter et al., 2016; Eisenhauer, 2016; Jiang et al., 2016) of these shifts are poorly understood. And with apparent increases in the uses of commercial microbial inoculants in soil during ecosystem management, there is a greater need to assess and mitigate any associated risks (Schwartz et al., 2006; Antunes et al., 2009).

While the drivers of soil biodiversity and the ecosystem consequences are addressed in sections 1 and 2, respectively, questions related to the belowground consequences of global environmental change and implications for soil management are summarized in this section.

\section{Global environmental change and biotic exchange}

37. What roles can soil biota play in ecosystem resistance and adaptation to global 
change, and what are the mechanisms underlying these contributions?

38. Is soil biodiversity currently undergoing an extinction crisis and, if so, to what extent is soil biodiversity being lost?

39. What is the role of soil organisms in plant range expansion, and to what degree can soil organisms migrate to favorable regions in response to climate change?

40. How resistant and resilient are ecosystems to changes in the composition and structure of soil communities?

41. What are the effects of land use change on trait composition and species composition of soil communities?

42. What is the relative importance of current versus historical processes in shaping species composition of belowground communities?

\section{Managing soils for ecosystem service provisioning}

43. How feasible is it to restore extensively degraded soil ecosystems to a functional state, and, if so, what roles can soil biota and ecological theory play in developing best practices for doing so?

44. What is the status and future of the generation of 'designer soils' that can 
provide a selected suite of ecosystem services in new (e.g., terraforming) or existing (e.g., restoration) environments?

45. Can we alter soil microbial communities to impart desired characteristics to plant products used in food, beverage, and materials production?

46. What advances in our understanding of soil ecology can lead to significant increases in agricultural production and sustainability?

47. How can research and knowledge from soil ecologists be better integrated with the social and economic sciences?

48. Are practices used in plant breeding for pest and disease resistance unintentionally selecting against mutually beneficial symbioses with microbes?

49. Can the value of soil quality and its effects on ecosystem services be quantified?

\section{New directions}

Many of the questions posed in response to the survey took the form of a 'wish list' for soil ecologists or a list of challenges that the discipline is facing from a practical perspective. While the responses indicated that there were many issues that would need to be addressed to ensure progress on the questions that were posed, the general mood was that most priorities 
were achievable. In total, $72 \%$ of the priorities raised were identified as achievable based on available technologies and analytical resources. However, in the responses, there was much more of a focus on the need for broad collaboration, stable funding for research, and innovation by soil ecologists in the ways that the above problems are thought about. Many respondents cited a greater need for coordinated approaches to research, engagement with the public and industry, and ensuring resources are available for advances to be made in the future. For instance, many open questions cannot be answered on a global scale because the necessary data is not available in central databases (Phillips et al., 2017), but several soil ecologists already have started initiatives to establish such databases, such as on soil biodiversity (Burkhardt et al., 2014; Ramirez et al., 2015; Cameron et al., 2016) or trait data (Pey et al., 2014; Nguyen et al., 2016). The rapid development and advancement of DNAbased analyses of soil biota is only one prominent example that offers new opportunities to disentangle links of biodiversity/species assemblages within or between different organization levels, such as among clades, functional groups, or trophic levels. However, merging the respective data in global databases in a way that allows straightforward data extraction and usage will require big collaborative and interdisciplinary efforts.

The respective list of questions is summarized in this section and may guide future research activities proposed above. Our aim here is to reflect current attitudes about the advances that need to be made to progress soil ecology as a discipline. Although some, or even all, of the topics below might not sound entirely new to certain soil ecology practitioners or to 
specialists developing new techniques, nor be issues that are only important to soil ecologists, we think that a broader discussion on these topics would be beneficial to the wider community of soil ecologists.

\section{New techniques and measurements}

50. Can we better integrate soil fauna into high-throughput analyses of soil biodiversity, perhaps through more effective approaches to sampling environmental DNA from soil and better designed primers for eukaryotic organisms?

51. How do we effectively characterize functional diversity and capacity in soil ecosystems instead of relying mainly on DNA sequencing?

52. Can we develop a comprehensive index of soil health that is a reliable and informative measure of soil quality?

53. Is it possible to visualize, in situ, soil processes (soil aggregate formation, interactions between biota etc.) in space and time at a level of resolution at which these processes are occurring?

54. Can we take a trait-based approach to biodiversity in soil ecology, and what 
would that look like?

55. Are there particular soil taxa that can be used as an indicator to assess the degree of impact associated with particular environmental stressors and perturbations?

56. How can we manipulate microbial communities to evaluate their functional roles without substantially altering the abiotic environment?

\section{New ways of thinking and working}

57. Can we establish long-term soil ecological observatories to track important issues, such as biodiversity loss and gradual environmental change?

58. How can we encourage open data sharing among soil ecologists (e.g., in open databases) in a way that ensures progress can be made without concerns arising with respect to the unethical use of these data?

59. Can we reverse the decline in taxonomic studies and recruit a new generation of taxonomists that are capable of integrating morphological evidence with an informed use of solid molecular databases?

60. How do we place soil biodiversity within a conservation perspective given the challenges we face with this 'enigmatic' system, such as extremely high 
diversity with much of it being cryptic or undescribed?

61. How can the public be engaged to appreciate the value of soil biodiversity?

62. How can we ensure that emerging soil ecologists receive the right training to address the questions identified in this paper?

63. Can we prevent soil ecology as a discipline from becoming too focused on technological tools and ensure an appropriate emphasis on addressing fundamental and applied questions in soil ecology?

\section{Conclusions}

The present survey identified sixty-three prioritized questions that may serve as a guide for soil ecological research. While some of the barriers to progress were technological in nature, many respondents cited a greater need for elements that can only be achieved with substantial leadership within and goodwill among members of the soil ecology research community. These include reversing the loss of important taxonomic expertise for many, if not all, groups of soil organisms; negotiating meaningful collaborative endeavors among researchers across many institutions in multiple countries; and securing funding for investigating the relevance of soil ecology to processes at large spatial and temporal scales. Global efforts such as the 
Global Soil Biodiversity Initiative (https://globalsoilbiodiversity.org/) suggest that this could be possible and may represent a starting point from which to build this concerted effort to address these questions. In addition, while the sample represented soil ecological researchers from 15 countries, there are large regions that still need to be canvassed, such as South and Central America, Africa, and several regions in Asia (Fig. 1), to ensure appropriate priorities are put in place for soil ecological research. Tackling the pressing questions listed above will not only be essential to advance basic soil ecological research, but will also generate crucial information for land managers and decision makers for a sustainable treatment of the soils that humankind relies on.

\section{Acknowledgements}

Nico Eisenhauer gratefully acknowledges funding by the Deutsche Forschungsgemeinschaft (DFG, German Research Foundation; Ei 862/2) and the European Research Council (ERC) under the European Union's Horizon 2020 research and innovation program (grant agreement no 677232). Further support came from the German Centre for Integrative Biodiversity Research (iDiv) Halle-Jena-Leipzig, funded by the German Research Foundation (FZT 118). Jeff Powell acknowledges funding from the Australian Research Council. Bryan Griffiths acknowledges funding from The Scottish Government's Rural and Environment Science and Analytical Services Division. Pedro M. Antunes acknowledges funding from the Natural 
Sciences and Engineering Research Council of Canada.

\section{References}

Antunes, P.M., Koch, A.M., Dunfield, K.E., Hart, M.M., Downing, A., Rillig, M.C., Klironomos, J.N., 2009. Influence of commercial inoculation with Glomus intraradices on the structure and functioning of an AM fungal community from an agricultural site. Plant Soil 317, 257-266. doi:10.1007/s11104-008-9806-y

Antwis, R.E., Griffiths, S.M., Harrison, X.A., Aranega-Bou, P., Arce, A., Bettridge, A.S.,... \& Fry, E.L., 2017. 50 important research questions in microbial ecology. FEMS Microbiology Ecology, https://doi.org/10.1093/femsec/fix044.

Bardgett, R.D., van der Putten, W.H., 2014. Belowground biodiversity and ecosystem functioning. Nature, 515, 505-511.

Blankinship, J.C., Niklaus, P.A., Hungate, B.A., 2011. A meta-analysis of responses of soil biota to global change. Oecologia, 165, 553-565.

Blaxter, M. L., De Ley, P., Garey, J. R., Liu, L. X., Scheldeman, P., Vierstraete, A., ... \& Vida, J. T. (1998). A molecular evolutionary framework for the phylum Nematoda. Nature, 392(6671), 71-75.

Burkhardt, U., Russell, D.J., Decker, P., Döhler, M., Höfer, H., Lesch, S., Rick, S., Römbke, J., Trog, C., Vorwald, J., Wurst, E., 2014. The Edaphobase project of GBIF-Germany-A new online soil-zoological data warehouse. Applied Soil Ecology, 83, 3-12.

Cameron, E.K., Decaëns, T., Lapied, E., Porco, D., Eisenhauer, N., 2016. Earthworm databases and ecological theory: Synthesis of current initiatives and main research directions. Applied Soil Ecology, 104, 85-90.

Ceballos, G., Ehrlich, P.R., Barnosky, A.D., García, A., Pringle, R.M., Palmer, T.M., 2015. Accelerated modern human-induced species losses: Entering the sixth mass extinction. Science Advances, 1, e1400253.

Deng, H., Yu, Y.J., Sun, J.E., Zhang, J.B., Cai, Z.C., Guo, G.X., Zhong, W.H., 2015. Parent materials have stronger effects than land use types on microbial biomass, activity and 
diversity in red soil in subtropical China. Pedobiologia, 58, 73-79.

Eisenhauer, N., 2016. Plant diversity effects on soil microorganisms: spatial and temporal heterogeneity of plant inputs increase soil biodiversity. Pedobiologia, 59, 175-177.

Eisenhauer, N., Bowker, M.A., Grace, J.B., Powell, J.R., 2015. From patterns to causal understanding: Structural equation modeling (SEM) in soil ecology. Pedobiologia, 58, 65-72.

Fierer N, Jackson RB. 2006. The diversity and biogeography of soil bacterial communities. PNAS 103:626-631.

Hewins, D.B., Fatemi, F., Adams, B., Carlyle, C.N., Chang, S.X., Bork, E.W., 2015. Grazing, regional climate and soil biophysical impacts on microbial enzyme activity in grassland soil of western Canada. Pedobiologia 58, 201-209.

Janion-Scheepers, C., Measey, J., Braschler, B., Chown, S.L., Coetzee, L., Colville, J.F., Dames, J., Davies, A.B., Davies, S.J., Davis, A.L. and Dippenaar-Schoeman, A.S., et al., 2016. Soil biota in a megadiverse country: Current knowledge and future research directions in South Africa. Pedobiologia, 59, 129-174.

Jiang, N., Wei, K., Chen, L., 2016. Long-term chronological shifts in bacterial communities and hydrolytic extracellular enzyme activities in the forty years following a land-use change from upland fields to paddy fields. Pedobiologia, 59, 17-26.

Johnson, S.N., Benefer, C.M., Frew, A., Griffiths, B.S., Hartley, S.E., Karley, A.J., Rasmann, S., Schumann, M., Sonnemann, I., Robert, C.A.M., 2016. New frontiers in belowground ecology for plant protection from root-feeding insects. Applied Soil Ecology, 108, 96-107.

Jones, C.G., Lawton, J.H., Shachak, M., 1994. Organisms as ecosystem engineers. Oikos 69, 373-386.

Keith, A.M., Schmidt, O., McMahon, B.J., 2016. Soil stewardship as a nexus between Ecosystem Services and One Health. Ecosystem Services, 17, 40-42.

Leff, J.W., Jones, S.E., Prober, S.M., Barberán, A., Borer, E.T., Firn, J.L., Harpole, W.S., Hobbie, S.E., Hofmockel, K.S., Knops, J.M., McCulley, R.L., 2015. Consistent responses of soil microbial communities to elevated nutrient inputs in grasslands across the globe. Proceedings of the National Academy of Sciences, 112, 10967-10972.

Maaß, S., Caruso, T., Rillig, M.C., 2015. Functional role of microarthropods in soil aggregation. Pedobiologia 58, 59-63. doi:10.1016/j.pedobi.2015.03.001 
Maestre, F.T., Delgado-Baquerizo, M., Jeffries, T.C., Eldridge, D.J., Ochoa, V., Gozalo, B., ... Bowker, M.A., 2015. Increasing aridity reduces soil microbial diversity and abundance in global drylands. Proceedings of the National Academy of Sciences, 112(51), 15684-15689.

Masson-Boivin, C., Giraud, E., Perret, X., \& Batut, J. (2009). Establishing nitrogen-fixing symbiosis with legumes: how many rhizobium recipes? Trends in Microbiology, 17(10), 458466.

McGill, B.J., Dornelas, M., Gotelli, N.J., Magurran, A.E., 2015. Fifteen forms of biodiversity trend in the Anthropocene. Trends in Ecology and Evolution, 30, 104-113.

Millenium Ecosystem Assessment, 2005. Ecosystems and human well-being: desertification synthesis. World Resources Institute, Washington DC, USA.

Moore, J.C., McCann, K., de Ruiter, P.C., 2005. Modeling trophic pathways, nutrient cycling, and dynamic stability in soils. Pedobiologia, 49, 499-510.

Neutel, A.M., Heesterbeek, J.A., Van de Koppel, J., Hoenderboom, G., Vos, A., Kaldeway, C., Berendse, F., De Ruiter, P.C., 2007. Reconciling complexity with stability in naturally assembling food webs. Nature, 449, 599-602.

Nguyen, N.H., Song, Z., Bates, S.T., Branco, S., Tedersoo, L., Menke, J., Schilling, J.S., Kennedy, P.G., 2016. FUNGuild: An open annotation tool for parsing fungal community datasets by ecological guild. Fungal Ecology 20, 241-248.

Orgiazzi, A., Bardgett, R.D., Barrios, E., Behan-Pelletier, V., Briones, M.J., Chotte, J.L., De Deyn, G.B., Eggleton, P., Fierer, N., Fraser, T., Hedlund, K., et al., 2016. Global soil biodiversity atlas. Luxembourg, Publications Office of the European Union, 176 pp.

Pey, B., Laporte, M.A., Nahmani, J., Auclerc, A., Capowiez, Y., Caro, G., Cluzeau, D., Cortet, J., Decaëns, T., Dubs, F., Joimel, S., 2014. A thesaurus for soil invertebrate trait-based approaches. PloS One, 9, e108985.

Phillips, D.A., Ferris, H., Cook, D.R., Strong, D.R., 2003. Molecular control points in rhizosphere food webs. Ecology, 84, 816-826.

Phillips, H.R.P, Cameron, E.K., Ferlian, O., Türke, M., Winter, M., Eisenhauer, N., 2017. Red list of a black box. Nature Ecology and Evolution, 1, article no 0103, doi:10.1038/s41559017-0103.

Powell, J.R., Eisenhauer, N., 2015. Pedobiologia in 2015: The International Year of Soils. 
Pedobiologia, 58, 57-58.

Powell, J.R., Craven, D., Eisenhauer, N., 2014. Recent trends and future strategies in soil ecological research-Integrative approaches at Pedobiologia. Pedobiologia, 57, 1-3.

Powell, J.R., Welsh, A., Hallin, S., 2015b. Microbial functional diversity enhances predictive models linking environmental parameters to ecosystem properties. Ecology, 96, 1985-1993.

Powell, J.R., Karunaratne, S., Campbell, C.D., Yao, H., Robinson, L., Singh, B.K., 2015b. Deterministic processes vary during community assembly for ecologically dissimilar taxa. Nature Communications, 6, article no 8444, doi:10.1038/ncomms9444.

Ramirez, K.S., Döring, M., Eisenhauer, N., Gardi, C., Ladau, J., Leff, J.W., Lentendu, G., Lindo, Z., Rillig, M.C., Russell, D., Scheu, S., et al., 2015. Toward a global platform for linking soil biodiversity data. Frontiers in Ecology and Evolution, 3, article no 91.

Rillig, M.C., Lehmann, A., Aguilar-Trigueros, C.A., Antonovics, J., Caruso, T., Hempel, S., Lehmann, J., Valyi, K., Verbruggen, E., Veresoglou, S.D. and Powell, J.R., 2016. Soil microbes and community coalescence. Pedobiologia, 59, 37-40.

Rooney, N., McCann, K., Gellner, G., Moore, J.C., 2006. Structural asymmetry and the stability of diverse food webs. Nature 442, 265-269. doi:10.1038/nature04887

Scherber, C., Eisenhauer, N., Weisser, W.W., Schmid, B., Voigt, W., Fischer, M., Schulze, E.-D., Roscher, C., Weigelt, A., Allan, E., Bessler, H., Bonkowski, M., Buchmann, N., Buscot, F., Clement, L.W., Ebeling, A., Engels, C., Halle, S., Kertscher, I., Klein, A.-M., Koller, R., König, S., Kowalski, E., Kummer, V., Kuu, A., Lange, M., Lauterbach, D., Middelhoff, C., Migunova, V.D., Milcu, A., Müller, R., Partsch, S., Petermann, J.S., Renker, C., Rottstock, T., Sabais, A., Scheu, S., Schumacher, J., Temperton, V.M., Tscharntke, T., 2010. Bottom-up effects of plant diversity on multitrophic interactions in a biodiversity experiment. Nature, 468, 553-556.

Scheu, S., 2001. Plants and generalist predators as links between the below-ground and above-ground system. Basic and Applied Ecology, 2, 3-13.

Schwartz, M.W., Hoeksema, J.D., Gehring, C.A., Johnson, N.C., Klironomos, J.N., Abbott, L.K., Pringle, A., 2006. The promise and the potential consequences of the global transport of mycorrhizal fungal inoculum. Ecology Letters 9, 501-515. doi:10.1111/j.14610248.2006.00910.x

Soliveres, S., Van Der Plas, F., Manning, P., Prati, D., Gossner, M.M., Renner, S.C., Alt, F., 
Arndt, H., Baumgartner, V., Binkenstein, J. Birkhofer, K., et al., 2016. Biodiversity at multiple trophic levels is needed for ecosystem multifunctionality. Nature, 536, 456-459, doi:10.1038/nature19092

Tedersoo, L., May, T.W., Smith, M.E., 2010. Ectomycorrhizal lifestyle in fungi: global diversity, distribution, and evolution of phylogenetic lineages. Mycorrhiza, 20(4), 217-263.

Thompson, R.M., Brose, U., Dunne, J.A., Hall, R.O., Hladyz, S., Kitching, R.L., Martinez, N.D., Rantala, H., Romanuk, T.N., Stouffer, D.B., Tylianakis, J.M., 2012. Food webs: reconciling the structure and function of biodiversity. Trends in Ecology and Evolution, 27, 689-697.

Van Dam, N.M., Bouwmeester, H.J., 2016. Metabolomics in the rhizosphere: tapping into belowground chemical communication. Trends in Plant Science, 21, 256-265.

Vellend, M., Dornelas, M., Baeten, L., Beauséjour, R., Brown, C.D., De Frenne, P., Elmendorf, S.C., Gotelli, N.J., Moyes, F., Myers- Smith, I.H., Magurran, A.E., 2017. Estimates of local biodiversity change over time stand up to scrutiny. Ecology, doi: 10.1002/ecy.1660

Venter, Z.S., Jacobs, K., Hawkins, H.-J., 2016. The impact of crop rotation on microbial diversity: a meta-analysis. Pedobiologia, 59, 215-223.

Veresoglou, S.D., Halley, J.M., Rillig, M.C., 2015. Extinction risk of soil biota. Nature Communications, 6, 8862 .

Wall, D.H., Nielsen, U.N., Six, J., 2015. Soil biodiversity and human health. Nature, 528, 6976.

Wardle, D.A., Bardgett, R.D., Klironomos, J.N., Setälä, H., Van Der Putten, W.H., Wall, D.H., 2004. Ecological linkages between aboveground and belowground biota. Science, 304, 1629-1633. 


\section{Figure}

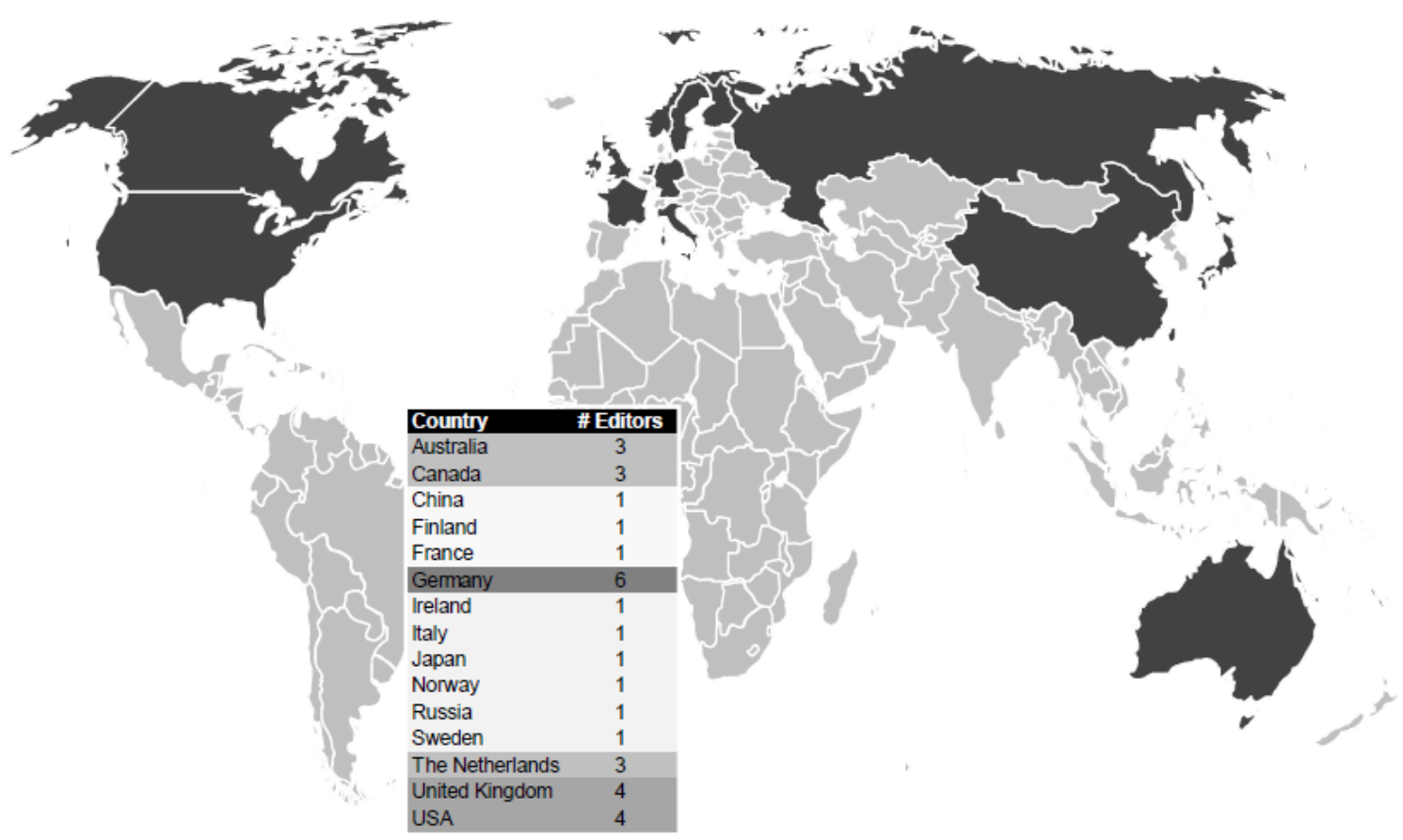

Figure 1. Geographic location of home institutes of the 32 Pedobiologia editors who participated in the present survey. In the map, countries represented by one or more editors are given in dark gray. In the table, different countries are given in alphabetical order, and countries represented by more than one editor are highlighted with different shades of gray. 


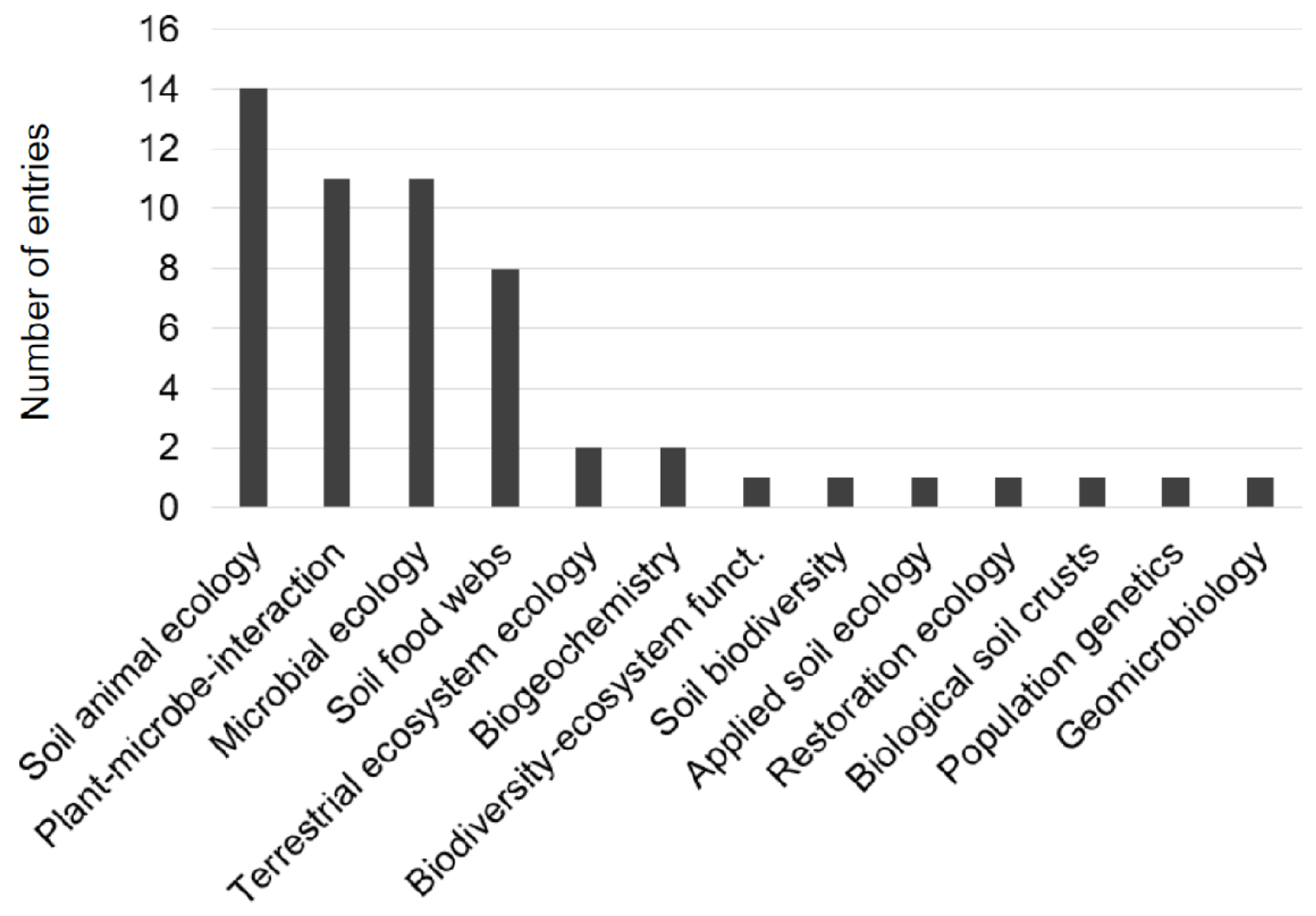

Figure 2. The 32 Pedobiologia - Journal of Soil Ecology editors who participated in the present survey represent different disciplines in soil ecology (multiple entries per editor were possible). 